DOI: $10.21802 / \mathrm{artm} .2020 .4 .16 .46$.

UDC 616-036.82+616.381-072.1+615.8

\title{
PROBABILITY OF MISDIAGNOSIS IN POLYCYSTIC OVARY SYNDROME
}

\author{
Y.A. Kyrylenko \\ National Technical University of Ukraine "Kyiv Polytechnic Institute named after Igor Sikorsky, Faculty of \\ Biomedical Engineering, Department of Biosafety and Human Health, Kyiv, Ukraine, \\ ORCID ID: 0000-0003-4897-8596, e-mail: liza.kirilenko.1998@gmail.com
}

Abstract. The purpose of this article was to convey information about polycystic ovary syndrome (PCOS), to reveal the information about the diagnosis of this syndrome and methods of treatment under various circumstances and reproductive plans. PCOS is now being diagnosed very often. However, frequently this is performed only on the basis of ultrasound diagnostics of the pelvic organs, which is not entirely correct. The picture of multi-follicular ovaries is just one of the symptoms of this syndrome, which may also indicate the presence of other disorders in the body.

This is the main reason why the wrong treatment is prescribed. After all, the wrong diagnosis is the key to the wrong treatment. It is important to understand that even with true PCOS, the most important thing is a woman's reproductive plans. When a woman has reproductive plans, COC therapy is out of the question. The realities of today are such that everyone needs to understand at least a little bit about the anatomy and physiology of their own body. This helps a lot to avoid misdiagnosis and, as a result, incorrect treatment, and also speeds up the search for the true cause of the problem. If misdiagnosed, the underlying problem is ignored, which can serve as a trigger for its aggravation and, as a result, its symptoms.

That is why everyone in our time needs to understand everything about it. So, for example, few people understand such things as: what is the menstrual cycle, how it should take place, what is its normal duration, what is the rate of discharge and in what periods of the menstrual cycle, is the pain normal at one time or another, and so on. Very often doctors of the old school prescribe, for example, COCs. Most importantly, this is often unnecessary. Also, in our society, after completing the COC course, the concept of "cancellation effect" was formed, which is not true.

Evidence-based medicine believes that eggs have several stages of growth and development, and only one of them is regulated by hormones. The rest of the stages proceed continuously and without stopping, and no exogenous or endogenous hormones can stop this. That is, the eggs always die regardless of whether you take COCs or not - this is an axiom. No method is able to prolong the childbearing age, since the ovarian reserve ends, it stops. The only thing that can save eggs is cryo-freezing. This method can be a solution for those who want to have their own children, but at the moment, for one reason or another, fertilization does not occur.

Yes, not all diseases can be cured, but even with those that are incurable, you need to learn to live and adapt, remove their manifestations and, if possible, reduce discomfort.

Even in the absence of complete recovery from a particular disease, it is necessary to understand that there are methods of physical therapy, diet and conventional drug therapy that can partially improve the condition. Recently, diet therapy has been actively discussed, namely the presence of a complete, balanced and rational diet for all, without exception.

In recent decades, fractional nutrition has shown its effectiveness. A balanced fractional nutrition allows you to provide the body with a sufficient amount of energy, to normalize the intestines, to ensure the normal functioning of the hormonal and nervous systems, etc.

What is PCOS and the main health problems in women associated with this syndrome? Can true PCOS be completely cured? The correct and complete diagnosis of PCOS and the main nuances of its "treatment" are offered.

Keywords: polycystic ovary syndrome, combined oral contraceptives, progesterone, follicles.

Introduction. Polycystic ovary syndrome (PCOS) is a heterogeneous disease, often called endocrine pathology of the reproductive system, which occurs in $5-10 \%$ of patients; characterized by the presence of anovulation and an excess of androgens of unclear etiology [2]. There is currently an assumption that this syndrome has a genetic component, although specific PCOS genes have not been identified yet.

Nowadays, PCOS is commonly diagnosed on the basis of ultrasound. However, it is necessary to understand the origin of this disease. Symptoms of this syndrome usually appear during puberty and sometimes even in adulthood.
The main signs of PCOS include skin problems, which are signs of elevated male hormones (hirsutism and acne); menstrual irregularities (less than eight menstrual periods per year); regular delay of menstruation (for 2-3 months or more); ultrasound picture of polycystic ovaries (one or both); obesity and insulin resistance (present in $75 \%$ of women with PCOS); infertility.

With PCOS, there are many small follicles in the ovary (one or two): 2 to $9 \mathrm{~mm}$ in size, but none of them can grow and become a dominant follicle. This gives us the understanding that with PCOS there is no regular ovulation, as the dominant follicle does not mature. This is where all the problems with conception come from. 
Rationale for the study. The main problem today is that the diagnosis of PCOS is erroneously made on the basis of ultrasound only, and regardless of women's reproductive plans, COCPs are prescribed.

Purpose: to convey true information about the diagnosis, mechanism of occurrence, and treatment of PCOS.

Materials and methods. In time absolutely no one can say the exact cause of PCOS - there are many many links involved in the pathogenesis.

First of all, insulin resistance is one of these links. Insulin resistance is when much more insulin is needed for glucose to enter a cell than normal. That is, the pancreas works at the border. High levels of insulin cause the ovaries to produce more androgens, which in turn prevents the maturation and growth of the dominant follicle. That is why it is not possible to ovulate in such a picture.

Insulin resistance can also lead to weight gain, which will only worsen the symptoms of PCOS, as excess adipose tissue leads to the even greater synthesis of insulin and androgens. High levels of insulin also reduce the synthesis of androgen-binding proteins - an increase in free androgens in the blood and disruption of the growth and maturation of the dominant follicle. The simplest and most commonly used test for insulin resistance is the HOMA index.

The second link in the pathogenesis of PCOS is considered to be an imbalance of hormones: elevated levels of male hormones (free testosterone, androstenedione, DHEA, and DHEF-c in the serum) and elevated levels of LH (it is this hormone that stimulates ovulation, rupture of the dominant follicle). should be high only within the female cycle, when the follicle is large enough, but if the LH level is high at the beginning of the female cycle, it interferes with the normal growth and development of the dominant follicle and stimulates the synthesis of male hormones by the ovaries, which inhibits ovulation.

With PCOS, estrogen levels are in the normal range, but progesterone levels are usually below normal because there is no ovulation. And if there is no ovulation, then what? It does not form a corpus luteum, which is the main source of progesterone. Lack of progesterone in normal amounts can lead to the endometrium becoming too thick - the so-called endometrial hyperplasia is formed. Prolonged hyperplasia can lead to endometrial cancer.

The third link in the pathogenesis of PCOS is nothing but genetics. It has been suggested that PCOS is associated with morphological changes directly in the ovaries (a thick protein shell that prevents ovulation and normal ovulation).

Having understood the pathogenesis of PCOS, we can talk about the diagnosis of this syndrome. Since PCOS is a syndrome, a certain set of signs and symptoms is needed, not the presence of one of them.

The diagnosis of PCOS can be made only based on of complaints, hormonal examinations, and ultrasound (that and not only). To make this diagnosis, the patient must have at least two of the three points listed below [1]: per year);

- Menstrual irregularities (less than eight periods

- Signs of elevated levels of male hormones (increased body hair growth, acne or male pattern hair loss androgenic alopecia), and preferably elevated androgen levels as a result of a blood test; lar) ovaries.

- Ultrasound signs of polycystic (multi follicu-

Standard hormonal examination for suspected PCOS includes blood tests for FSH, LH, TSH (to rule out thyroid disease), 17-OP (to rule out congenital adrenal dysfunction), prolactin, and some androgens - testosterone, DHEA-c).

When PCOS is confirmed, an additional blood test is usually performed to determine glucose and cholesterol levels.

Research results. Concerning the treatment of PCOS, the mechanism of this disease can be concluded that this syndrome is incurable. After all, it is impossible to make new receptors appear in the ovaries so that these receptors have a good sensitivity on a constant basis and they regularly grow a dominant follicle. It is impossible to affect genes, to force the pituitary gland to synthesize a normal amount of $\mathrm{LH}$ at the beginning of the menstrual cycle [3].

All that is possible is to affect some points (and temporarily) with symptomatic treatment. For example, when a woman takes COCs (combined oral contraceptives), the levels of $\mathrm{LH}$ and androgens will decrease, but as soon as COCs are discontinued, everything will return to normal.

"Treatment" of PCOS is carried out only when a woman has less than 6-8 menstrual periods per year, has a problem of hirsutism or acne and infertility. In all other cases, no interventions are performed.

When prescribing treatment, a woman's reproductive plans are a crucial issue. If there are currently no reproductive plans, the following treatments may be suggested [1]:

1. COC. It should be understood that this is only symptomatic treatment, not a magic pill that will get rid of PCOS once and for all - after the abolition of therapy, menstruation will be just as irregular. COCs are used to protect the endometrium from hyperplasia and cancer, eliminate acne and hirsutism, reliable contraception (because sometimes PCOS still ovulates, if there is a risk of getting pregnant). There is one very important point: if a woman wants to get pregnant, she cannot be recommended and prescribed COCs. There is no rebound effect - this is a myth. It should be understood that the follicles in the ovaries have different stages of maturity (there are three): the first stage is independent of hormones and lasts 120 days, the second lasts about 65 days before the antral follicle stage, and the last (third stage) depends on the follicular phase of menstruation. cycle and lasts an average of 14 days. COCs interfere with only the third stage of oocyte maturation, and even if the follicle does not pass it, it still dies because it cannot wait or be preserved - this is a simple law of biology (the process of folliculogenesis is continuous, autonomous, and cannot be stopped). 
2. Vaginal hormonal ring or hormonal patch. The approach and purpose of therapy are the same as when taking COCs.

3. Hormonal IUD containing progesterone protects the endometrium from hyperplasia and cancer, is not effective in eliminating acne and hirsutism.

4. Progestins - synthetic progesterone. Cyclically taken for 10-14 days every 1-3 months. This treatment protects the endometrium. Taking progesterone from the 16 th to the 25th day of the cycle will not help you get pregnant - it is crucial to understand. After all, low progesterone levels are only a consequence of anovulation, not its root cause.

If a woman has been diagnosed with PCOS and she wants to get pregnant, then first of all, if you are overweight or obese, you need to lose weight. Sometimes that alone is enough.

The second step is usually the appointment of stimulating (inducing) ovulation drugs, such as clomiphene citrate or letrozole. The second step usually results in ovulation in $80 \%$ of women with PCOS, and about 50 $60 \%$ of them become pregnant.

If ovulation and pregnancy do not occur with the two-step medication, gonadotropins (FSH injections) are offered, in which case pregnancy occurs in $70 \%$ of cases. If this does not help, then the next step is laparoscopic drilling (removal of the ovary - wedge resection) of the ovaries or pregnancy by IVF [1].

Discussion of results. To start working on losing weight, you need to understand one simple truth: to lose weight, you need to spend more calories than you eat. This is usually achieved by adjusting the diet and increasing daily physical activity [3].

To date, proper nutrition is considered to maintain normal blood sugar levels. The main postulates of proper nutrition are small portions; small meals; giving preference to complex carbohydrates, lean protein and proper fats (vegetable or animal, not trans fats); eating enough vegetables (fiber); avoidance of long breaks between meals - more than 4 hours; drinking enough water.

Today, there is a Mifflin-San Gior formula for calculating calories for a particular person, taking into account his level of physical activity, age, height, sex, and weight. In my experience, this is the best formula available today.

First of all, the indicator of basic metabolism $(\mathrm{BM})$ is calculated - the amount of energy consumed at rest. For women, this figure is:

$\mathrm{BM}=9.99 *$ body weight $(\mathrm{kg})+6.25 *$ height (cm) $+4.92 *$ age (years) -161

For men:

$\mathrm{BM}=9.99 *$ body weight $(\mathrm{kg})+6.25 *$ height $(\mathrm{cm})+4.92 *$ age $($ years $)+5$

A very common mistake is that the value of $\mathrm{BO}$ is considered the daily norm of calorie intake (DNCI). The indicator of DNCI takes into account the indicator of physical activity, in contrast to BO. To calculate the value of DNCI it is necessary to multiply the BM by the activity factor (AF) of a particular person.

You need to understand that calories are energy. The amount of energy needed by a single mother to look after an infant alone and the amount of energy needed by an office worker to climb to the top of his office and go back to the car are two different amounts of energy, respectively. two different indicators of spacecraft and DNCI.

In practice, the spacecraft is divided as follows:

- $\mathrm{AF}=1,2$ - minimum loads, sedentary work, movement by car;

- $\mathrm{AF}=1,375$ - more daily activity, light exercise daily or light training in the gym 3 times a week, daily walks (7-10 thousand steps);

- $\mathrm{AF}=1.46$ - training 4-5 times a week of medium intensity or work of medium severity;

- $\mathrm{AF}=1.63$ - daily training;

- $\mathrm{AF}=1.73$ - daily training or training twice a day;

- $\mathrm{AF}=1.9$ - intensive training twice a day or hard physical work (miner).

It is also necessary to take into account the indicator of the specific action of food (SAF) - specific dynamic action of food; the body's energy expenditure associated with the consumption and digestion of food. The average SDDI is $10 \%$ of the BO. Therefore, the daily requirement of calories (DRC) is calculated as:

$\mathrm{DRC}=(\mathrm{BM}+\mathrm{SAF}) * \mathrm{AF}$

$\mathrm{DRC}$ is the main indicator of calories to maintain weight. Based on this indicator, we can make adjustments. If the goal is to lose weight, subtract $10-15 \%$ from DRC. Conversely, add $10-15 \%$ if the goal is to gain weight.

The most correct choice is a gradual adjustment of nutrition. The first thing to change is to introduce dinner 2-3 hours before bedtime (dinner should contain protein and fiber). After that, it will be easier to fall asleep and wake up, because with this version of dinner there will be no full stomach and in the morning the person will wake up hungry.

For the first meal - breakfast should ideally contain complex carbohydrates, protein, and fats. In the morning, blood sugar is lowered after sleep, so it is recommended to refrain from eating simple carbohydrates. It is better to eat them for the first snack - a meal between breakfast and lunch. The most useful option for the first snack is fruit.

This meal is very important and useful for cheating, especially during ovulation or during premenstrual syndrome (PMS) when there is a sharp change in the hormonal status of the body. During such periods, you often want to eat "something fatty or sweet", for which the first snack is ideal.

The same combination of macronutrients is usually eaten for lunch for breakfast. After lunch, it is recommended not to eat simple carbohydrates, as they are broken down very quickly, causing a rapid jump in blood sugar. And the excess is always deposited in fat.

For the second snack, the use of protein and fiber or vegetable fats is relevant. The diet of most people is characterized by a lack of normal amounts of vegetable fats in the diet, despite the recommendation to consume at least 1 gram of fat per $1 \mathrm{~kg}$ of body weight $(70 \%$ of fats should be of vegetable origin, and $30 \%$ - animal).

It is very important to monitor the use of sufficient water: the formula for calculating the daily norm of water $-30 \mathrm{ml}$ of water per $1 \mathrm{~kg}$ of body weight [4]. 
As for daily loads, it is recommended not to lift too much weight.

In view of the above, Kegel exercises can be recommended, as these exercises play an important role in a woman's health and her reproductive function and sexual life. Constant performance of a set of exercises to strengthen the pelvic floor muscles, as their performance is accompanied by oxygen saturation of the muscles, which reduces the symptoms of discomfort in everyday life.

The easiest and most popular are two Kegel exercises: "hold" and "lift".

To perform the exercise "hold" you need to squeeze the pelvic floor muscles as much as you can, and stay in this state for the maximum possible time for you (ideally, reach a time of 10 seconds). Perform this exercise should be 5-7 repetitions, each time increasing the time of muscle tension by 1-2 seconds. The purpose of this exercise is a static load: the muscles of the pelvic floor are affected by statics, making them more sensitive and elastic, improves metabolism, increases strength.

To perform the "Elevator" exercise, you need to imagine that you are climbing an elevator. Tighten the pelvic floor muscles more as soon as the "elevator" reaches a new floor. Having "risen" on 10-15 floors (as much as there will be enough forces, for a start 2-3 floors are enough), start "going down", as gradually and consistently relaxing muscles. Exercise dosage: 3-4 full ascents and descents. Prolonged step tension is also a kind of static load with all the consequences for the pelvic floor muscles.

Conclusion. The realities of today are such that everyone needs at least a little understanding of the anatomy and physiology of their own body. This helps a lot to avoid misdiagnosis and, consequently, wrong treatment and speeds up finding the real root cause of the problem. Even in the absence of complete recovery from a particular disease, it is necessary to understand that there are methods of physical therapy, diet, and our usual drug therapy, which can partially improve the condition.

\section{References:}

1. Belokon O. I am a woman. All about hormones, contraception, and women's health. 2018. P.62-119.

2. Article from the Internet resource: https:/ua.iliveok.com/health/syndrom-polikistoznyhyayechnykiv_76036i15953.html.

4. Nadia Brio Pateguana, Jason Fung, "The PCOS plan", Prevent and reverse PCOS through Diet and Fasting. 2020.

5. Butov AV, Novikova A, Rachina A. Additional material for the course "Theory and practice of effective bodybuilding". 2019. P.90.

6. Press227 recommends! Electronic resource - URL: https://www.youtube.com/user/press227

7. Shalamov RV, Pidhirnyi VI. Biology. Grade 9: a brief guide. 2010. P.176.

8. Molotova H. My best friend is the stomach. Food for smart people. 2016. P.360.

9. Zubareva N. Waltz of hormones: weight, sleep, sex, beauty and health as per the notes. 2018. P.351.
10. Parkhotnik II. Physical rehabilitation in diseases of the abdominal cavity. 2003. P.223.

11. Marchenko OK, Fundamentals of physical rehabilitation. 2012. P.528.

12. Smirnova E. Intimate gymnastics for women. 2016. P.480.

\section{УДК 616-036.82+616.381-072.1+615.8 \\ ІМОВІРНІСТЬ ПОМИЛКОВОГО ДІАГНОЗУ ПРИ СИНДРОМІ ПОЛІКІСТОЗНИХ ЯЕЧНИКІВ}

\section{Є.О. Кириленко}

Національний технічний університет Украӥни «Київський політехнічний інститут імені Ігоря Сікорського», факультет біомедичної інженерії, кафедра біобезпеки та здоров'я людини, м. Київ, Україна,

ORCID ID: 0000-0003-4897-8596,

e-mail: liza.kirilenko.1998@gmail.com

Резюме. Метою написання статті було донести інформацію про синдром полікістозних яєчників (СПКЯ), діагностику цього синдрому і методи лікування при різних обставинах і репродуктивних планах. СПКЯ в наш час діагностується дуже часто. Однак здебільшого це виконується тільки на підставі ультразвукової діагностики органів малого тазу, що не зовсім правильно. Картина мультифолікулярних яєчників - це всього лише один 3 симптомів цього синдрому, який може свідчити також про наявність інших порушень в організмі.

Це основна причина, через яку призначається неправильне лікування. Адже неправильний діагноз ключ до неправильного лікування. Важливо розуміти, що навіть при щирому СПКЯ найважливіше - це репродуктивні плани жінки. Коли у жінки є репродуктивні плани, про терапію КОК не може бути й мови. Реалії сьогодення такі, що кожному потрібно хоч трохи розбиратися в анатомії і фізіології власного тіла. Це дуже допомагає уникнути помилкового діагнозу i, як наслідок, неправильного лікування, а також прискорює пошук справжньої причини проблеми. При неправильному діагнозі ігнорується основна проблема, що може служити спусковим гачком для іiі посилення i, як наслідок, іiі симптомів.

Саме тому кожному в наш час необхідно розуміти хоча б базові поняття анатомії та фізіології людини. Дуже часто лікарі старого гарту призначають, наприклад, КОК. Найголовніше, що часто в цьому немає необхідності. Також в нашому суспільстві після проходження курсу КОК сформувалося поняття «ефект відміни», що не відповідає дійсності.

Що таке СПКЯ, і які основні проблеми зі здоров'ям у жінок пов'язані з цим синдромом? Чи можна повністю вилікувати істинний СПКЯ? Пропонується правильне і повне діагностування СПКЯ та описується як можна мінімізувати негативний вплив на організм цього синдрому. 
Ключові слова: синдром полікістозних яєчників, комбіновані оральні контрацептиви, прогестерон, фолікули.

\section{УДК 616-036.82+616.381-072.1+615.8 \\ ВЕРОЯТНОСТЬ ОШИБОЧНОГО ДИАГНОЗА ПРИ СИНДРОМЕ ПОЛИКИСТОЗНЫХ яИЧнИкОВ}

\section{Е.А. Кириленко}

Нацииональный технический университет Украины «Киевский политехнический институт имени Игоря Сикорского», факультет биомедицинской инженерии, кафедра биобезопасности и здоровья человека, г. Киев, Украина,

ORCID ID: 0000-0003-4897-8596,

e-mail: liza.kirilenko.1998@gmail.com

Резюме. Целью написания данной статьи было донести информацию о синдроме поликистозных яичников (СПКЯ), о диагностике данного синдрома и о методах лечения при различных обстоятельствах и репродуктивных планах. СПКЯ в настоящее время диагностируется очень часто. Однако очень часто это выполняется только на основании ультразвуковой диагностики органов малого таза, что не совсем правильно. Картина мультифолликулярных яичников это всего лишь один из симптомов данного синдрома, который может свидетельствовать также о наличии других нарушений в организме.

Это основная причина, по которой назначается неправильное лечение. Ведь неправильный диа- гноз - ключ к неправильному лечению. Важно понимать, что даже при истинном СПКЯ, самое важное это репродуктивные планы женщины. Когда у женщины есть репродуктивные планы, о терапии КОК не может быть и речи. Реалии сегодняшнего дня таковы, что каждому нужно хоть немного разбираться в анатомии и физиологии собственного тела. Это очень помогает избежать ошибочного диагноза и, как следствие, неправильного лечения, а также ускоряет поиск истинной причины проблемы. При неправильном диагнозе игнорируется основная проблема, что может служить спусковым крючком для ее усугубления и, как следствие, ее симптомов.

Именно поэтому каждому в наше время необходимо понимать хотя бы базовые понятия анатомии и физиологии человека. Очень часто врачи старой закалки назначают, например, КОК. Самое главное, что часто в этом нет необходимости. Также в нашем обществе после прохождения курса КОК сформировалось понятие «эффект отмены», что не соответствует действительности.

Что такое СПКЯ, и какие основные проблемы со здоровьем у женщин связанные с этим синдромом? Можно ли полностью вылечить истинный СПКЯ? Предлагается правильное и полное диагностирование СПКЯ и описывается как можно минимизировать негативное влияние на организм этого синдрома.

Ключевые слова: синдром поликистозных яичников, комбинированные оральные контрацептивы, прогестерон, фолликулы.

Стаття надійшла в редакцію 03.12.2020 р. 